\title{
An assessment of students' job preference using a discrete choice experiment: a postgraduate case study
}

\author{
Henry Gyarteng-Mensah and De-Graft Owusu-Manu \\ Kwame Nkrumah University of Science and Technology, Kumasi, Ghana
}

David Edwards

School of Engineering and the Built Environment, Birmingham City University, Birmingham, UK

Isaac Baidoo

University of Ghana, Accra, Ghana, and

Hatem El-Gohary

Qatar University College of Business and Economics, Doha, Qatar
Assessment of students' job preference

Received 9 February 2020 Revised 29 September 2020 6 December 2020 Accepted 7 December 2020

\begin{abstract}
Purpose - Using a discrete choice experiment (DCE), this study aims to better understand the job preference of postgraduate students studying at the Kwame Nkrumah University of Science and Technology-Institute of Distance Learning, Ghana and also rank the attributes of a job they deem important.

Design/methodology/approach - The research adopted a positivist epistemological design contextualised within a deductive approach and case study strategy. Primary survey data was collected from a stratified random sample of 128 postgraduate students with multi-sectorial career prospects. Sample students were subjected to a DCE in which their stated preferences were collected using closed-ended questionnaires with 28 pairs of hypothetical job profiles. Respondents' preferences from the DCE data were then modelled using the conditional logit.
\end{abstract}

Findings - The research reveals that: salary in the range GHC 2,800.00 to GHC 3,400.00 (\$1 = GHS 5.3); supportive management; very challenging jobs; and jobs located in the city were the top attributes that were significant and had the most impact in increasing the utility of selecting a particular job. Interestingly, jobs with no extra hours workload were not significant hence, had a negative impact upon student preferences.

Originality/value - This novel research is the first to use a DCE to better elicit preference and trade-offs of postgraduate students in a developing country towards varying job characteristics that have an impact on their future employment decisions. Knowledge advancements made provide invaluable insight to employers and policymakers on the key criteria that should be implemented to retain the best candidate.

Keywords Utility, Preference, Attributes, Postgraduate students, Discrete choice experiment Paper type Research paper

(C) Henry Gyarteng-Mensah, De-Graft Owusu-Manu, David Edwards, Isaac Baidoo and Hatem El-Gohary. Published in Journal of Humanities and Applied Social Sciences. Published by Emerald Publishing Limited. This article is published under the Creative Commons Attribution (CC BY 4.0) licence. Anyone may reproduce, distribute, translate and create derivative works of this article (for both commercial and non-commercial purposes), subject to full attribution to the original publication and authors. The full terms of this licence maybe seen at http://creativecommons.org/licences/by/4.0/legalcode

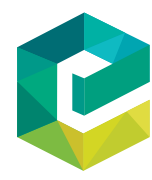

Journal of Humanities and Applied Social Sciences Vol. 4 No. 3,2022 pp. $159-178$

pp. 159-178
Emerald Publishing Limited 2632-279X 
JHASS
4,3

160

\section{Introduction}

Humans have the innate capacity to express their preferences based on certain characteristics of the subject matter at their disposal - and from these characteristics, individuals gain different utility. The selection of a "job" or "career" (terms that are herein used interchangeably) by a student is one of many decisions that may have an impact upon their future aspirations (Edwards and Quinter, 2011). Edwards and Quinter (2011) further assert that with the ever-increasing development in information technology (Newman et al., 2020) and the sudden rise of the post-industrial revolution (Edwards et al., 2017; Roberts et al., 2018; Aghimien et al., 2020) and increasing job competition, career preference has become a complex science for individuals. To attract medium-to-long term employees, employers should focus on both monetary attributes and non-monetary attributes of a job (Demel et al., 2019). Factors that affect the career preference of an individual may be categorised into extrinsic, interpersonal and intrinsic or altruistic (Sibson, 2011). These categories include a plethora of variables including: an enjoyable working environment; good career opportunities; job security; ability to have a positive impact upon society; flexible hours of work; and a good starting salary. Some academics proffer that most employees focus primarily on extrinsic factors such as economic rewards while conversely, others suggest that employee career preferences are increasingly affected by intrinsic factors (Gallie et al., 2012). However, and hitherto, scant research investigation has been conducted in most developing countries to uncover key considerations that lie behind an individual's career preferences using various job characteristics. This area delineated upon requires urgent research attention to assist employers and policymakers who seek to attract and retain the best qualified candidate. Career factors and variables that influence a graduate's career preference are extensive and largely unknown within the context of a developing countries context. Yet, graduates are instrumental to economic development and prosperity in developing countries.

According to Arokiasamy (2013), the staff turnover rate in organisations is one of the most costly human resource (HR) challenges within developing countries. Consequently, employers who possess no prior knowledge about the graduate's preferences at the time of their employment risk increasing their organisation's labour turnover rate. This problem creates a major hurdle for employment organisations who seek to formulate appropriate HR policies (Rehman, 2012) despite having limited empirical evidence on the importance of different job characteristics on their graduates' job preferences. Sibson (2011) opined that to attract and retain the best students, industry and commerce should seek to better understand what students identify as important in a career because knowledge of such helps with efforts to retain highly valued staff. Authors such as Olamide and Oluwaseun (2013) used simple ranking and rating data to conclude that the factors of environment, influence and opportunity affect graduates' employment choices when determining their career. The limitation of this research (Olamide and Oluwaseun, 2013) is that applicants generally look at the attributes that define the job evaluating each attribute "individually" hence, using these methods fail to actually reflect respondent preferences when they are asked to rank a list of "subjective" attributes (Demel et al., 2019). Olamide and Oluwaseun (2013) also failed to report upon students' preferences with regard to a given career attribute and attribute level. Consequently, their work (Olamide and Oluwaseun, 2013) did not support the theory of "random utility", which states that a respondent is assumed to choose the alternative that constitutes their highest priority (Lancaster, 1966). The theory further states that consumers (i.e. graduates) derive utility not from goods per se but rather from the attributes or characteristics that the goods possess. 
To address these knowledge gaps, this research uses the discrete choice experiment (DCE) to elicit respondents' job stated preferences and assess the range of attributes that impact upon their preferences. Moreover, the work also develops an opposite job preference model using Lancaster's (1966) random utility theory as the basis. DCE is primarily used where the understanding of preferences from an individual's behaviour is difficult to ascertain (Mangham and Hanson, 2008) and are generally used in health economics and transportation studies. This model developed and concomitant contributions to new knowledge, will prove invaluable to employers, policymakers and recruitment agencies who seek to formulate employment selection policies that augment retention levels.

\section{Employee turnover and retention}

An organisations' well-being depends on its employees and one challenge facing employers is employee retention, which can adversely effect productivity performance and profitability when turnover is high (Arokiasamy, 2013; Agyeman et al., 2014). Rehman (2012) opined that the negative effect of turnover may comprise tangible or intangible costs associated with the development of new employees, the distraction of job performance, delays to project programmes, etc. To remain competitive, organisations must attract and retain the highest calibre talent (Kossivi et al., 2016). The turnover and retention rates of employees vary from one employer to the other because of employees' individual preferences. Labour turnover (Booth and Hamer, 2007; Agyeman et al., 2014) can be categorised into environmental and organisational factors. Building upon the aforementioned, the Herzberg two factor theory model proposed that any factors, which impact upon an employee's satisfaction or dissatisfaction may be termed as motivators (satisfiers) and hygiene (dissatisfiers) factors. Motivators are intrinsic factors that influence employees in an organisation whereas hygiene factors are extrinsic and include: job security; salary; and benefits - failure to incorporate these hygiene factors within a job role often leads to dissatisfaction and poor staff retention (Ball, 2003). Figure 1 reproduces the Hyzberg theory.

To reduce employee turnover rates, HR management must comprehend factors, which play a vital role in postgraduate students' retention. Ghapanchi and Aurum (2011) stated that: remuneration and fringe benefits; training opportunities; fair and equal treatment; and organisational cultures were contributing factors to retention and turnover.

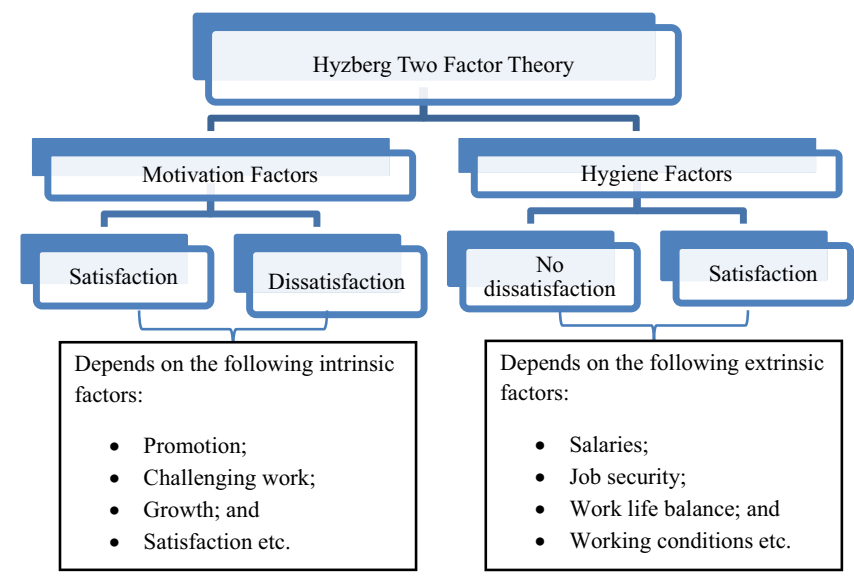

Assessment of students' job preference

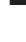




\section{JHASS 4,3}

\section{Attributes that influence preferences of a job}

In an increasingly competitive global market (Edwards et al., 2017; Owusu-Manu et al., 2019), the employability of the best graduates has become an important consideration that underpins commercial success or failure (Nwogu and Momoh, 2015). For the graduate, selecting the right job is, perhaps, the most important decision taken at the outset of a career because such could impact upon their life and any decisions they may take - such as buying a home and starting a family (Olamide and Oluwaseun, 2013). Nwogu and Momoh (2015) proffer that dissatisfaction with the nature of a job and/or job insecurity were stronger influencers for graduates to change jobs than dissatisfaction with pay. Sibson (2011) observed that nursing graduates place low priority on financial rewards and prestige but rather place more emphasis upon working and caring for people, and attaining equilibrium in their work-life balance. Demel et al. (2019) observed that, salary and commuting distance had a positive and negative impact on postgraduate students' preferences, respectively. Many employees attach importance to extrinsic factors such as pay, promotion prospects and other fringe benefits with some attaching low importance to training opportunities (Gallie et al., 2012). Stebleton (2007) proposed numerous external factors that affect or influence students' career choices; these external factors include: political and economic considerations; previous work experience; and the influence of key individuals in a person's life. Edwards and Quinter (2011) suggested that gender and environmental reasons were the least influential factors that may affect career choice and suggested that, the environment in which an individual develops will invariably shape their interests but not directly influence choices made. Mangham and Hanson (2008), observed that the attributes: opportunity to upgrade qualifications, provision of basic government, housing and increases in net monthly pay had the greatest impact on the respondents' utility of taking up a particular job over the other. Lagarde and Blaauw (2011) opined jobs located in rural areas had a negative impact on respondents' choice, with Kolstad (2010) suggesting that to ensure an efficient matching of individuals and sectors, it may be worthy to have two sectors by allowing employers in these sectors to use different payment mechanisms designed to attract and support worthy performance from different types of workers. Retention of individuals could be improved by designing quite different job packages to appeal different tastes with salary remaining an important factor in making jobs attractive (Doiron et al., 2014).

\section{Demography cohort and job preference}

Gender is important when making career choices because gender role socialisation leads men and women to evaluate job attributes differently (Barbulescu and Bidwell, 2013). Behaviour is acquired from the environment through a process of observational learning, mediating processes between stimuli and response (Bandura, 1977). Because of this, female children grow-up learning family values and so consequently, seek jobs with low workload to secure family time (Kretchmar, 2009). The importance of job preferences for women generally depends on their birth generation (Gallie et al., 2012). Conversely, male children mature in the belief that they are the family financier, and therefore, may engage in extra work hours to seek a higher salary to maintain the home. According to Gallie et al. (2012), women born in earlier decades were primarily believed to be, and were seen as, homemakers. Chusmir and Parker (1991) supported this claim by stating that women are more inclined towards work that provides a flexible working schedule, less demanding job and family friendly policy that allows them to fulfil dual roles as employees and homemakers. Of course, these are broad statements and in contemporary times (particularly in the West), the roles and values of both men and women are more equal while in developing countries, attitudes will continue to change in future generations. 


\section{Theoretical foundation}

Various theories and methodologies underpin this study and in particular, the random utility theory is particularly important.

\section{Random utility theory}

Random utility theory underpins a DCE, which assumes that individuals maximise utility (Vooren et al., 2019); where utilities of an individual can be summarised by two components, namely, systematic; and random. The systematic component is made up of attributes that impact an individual's choice whereas random components consists of all unidentified factors that influence the choice (Louviere et al., 2010). It is assumed that the random utility of alternative $\mathrm{i}, \mathrm{Ui}$, for an individual in random utility models take the form:

$$
\mathrm{Uij}=\mathrm{Vij}+\mathrm{Eij}
$$

Uij is the utility of alternative $\mathrm{j}$ for consumer $\mathrm{i}$, where Vij is the deterministic component and Eij is the random component or error term. Raghavarao et al. (2011) stated that the random utility $(\mathrm{U})$ assumes that on a given choice set, individuals choose the alternative they deemed to have the greatest utility on that occasion; thus, alternative $i$ is preferred to alternative $j$ if, and only if, utility (Ui $>\mathrm{Uj})$. As the researcher cannot observe an individual's true utility function, a probabilistic utility function is used in the estimation (Raghavarao et al., 2011), namely, assume an individual choosing between two alternatives, $\mathrm{i}$ and $\mathrm{j}$, then the probability that alternative $i$ is chosen is given by:

$$
\mathrm{Pi}=\operatorname{Prob}(\mathrm{Ui}>\mathrm{Uj})=\operatorname{Prob}(\mathrm{Vi}+\mathrm{Ei}>\mathrm{Vj}+\mathrm{Ej})=\operatorname{Prob}(\mathrm{Vi}-\mathrm{Vj}>\mathrm{Ej}-\mathrm{Ei})
$$

A product's attractiveness can be related to its attributes and so the factors that influence preference must be identified and included prior to data collection and modelling (Adamowicz and Louviere, 1998). These attributes can be derived from focus groups that are tailored to a particular project, literature sources, prior experience with the same or similar products or services and/or from a combination of different approaches. Therefore, preference data can be analysed using methods that are compatible with random utility theory (Clark et al., 2014). Thus, attributes that are used for each job description should be the main factors influencing respondents' job preference (Mangham and Hanson, 2008).

\section{Approach to preference measurement}

The outcome of an individual's preference can be assessed using either the revealed preference theory or the stated preference approach. Understanding the impact on how the characteristics of alternatives affect preferences for goods or services is important in scientific fields where predicting human choice is of interest (Raghavarao et al., 2011).

\section{Revealed preference}

Revealed preference deals with the inferences that are made from the observation of an individual's actual market behaviour. Under the revealed preference, it is assumed that the individual's preferred alternatives (from different feasible sets) are being recorded by an observer (Nishimura et al., 2016) and that there should be a market demand curve for the goods in question for which the preference is being made (Kjær, 2005). Revealed preference studies seek to make sense from the observed individual's behaviour. For instance, if an individual prefers Job A over Job B, it is assumed that the individual's preferences are stable
Assessment of students' job preference 
$\underset{4,3}{\text { JHASS }}$

164

over the observed time period, i.e. the individual will not reverse their relative preferences regarding career A and B (Raghavarao et al., 2011).

\section{Stated preference}

The stated preference addresses most limitations of the revealed preference. In stated preference, the observations of real market behaviour of individuals are not employed but rather individuals are invited to compare hypothetical scenarios (Kjær, 2005). Raghavarao et al. (2011) stated that uncertain and ambiguous indications are eliminated so that all respondents have the same information and no more.

\section{Stated preference versus revealed preference}

Table 1 represents a side-by-side comparison of revealed and stated preference; where the weakness of one is complemented by the other.

Although the revealed preference theory can be adopted for this study, it is generally limited to helping researchers understand preferences hence, justification for using the stated preference approach (Nyarko et al., 2015).

\section{Discrete choice experiment}

The basic concern of economics is to better understand human preference behaviour (McFadden, 1974). DCE is a methodology used to elicit preferences from respondents who are presented with a hypothetical scenario with not more than five attributes (each with their respective levels (York Health Economics Consortium, 2016)) and it is used in studies where revealed preference data is difficult to obtain or is absent (Mangham et al., 2009). To

\begin{tabular}{|c|c|c|c|}
\hline Factor & Revealed preference & Stated preference & References \\
\hline Approach & $\begin{array}{l}\text { The preferences of individuals are } \\
\text { determined by studying their real } \\
\text { market behaviour }\end{array}$ & $\begin{array}{l}\text { Individuals are asked to state their } \\
\text { preference using a hypothetical } \\
\text { situations or scenarios }\end{array}$ & $\begin{array}{l}\text { Nyarko et al. } \\
\text { (2015), Kjær } \\
(2005)\end{array}$ \\
\hline Alternatives & $\begin{array}{l}\text { Actual alternatives responses to } \\
\text { non-existing alternatives are not } \\
\text { observable }\end{array}$ & $\begin{array}{l}\text { Preferences of new alternatives } \\
\text { can be elicited from generated } \\
\text { alternatives }\end{array}$ & Morikwa (1994) \\
\hline Attributes & $\begin{array}{l}\text { May include highly correlated } \\
\text { attributes }\end{array}$ & $\begin{array}{l}\text { High correlation eliminated by an } \\
\text { experimental design }\end{array}$ & Morikwa (1994) \\
\hline Choice set & $\begin{array}{l}\text { Not generally specific in some } \\
\text { cases }\end{array}$ & Pre-specified or pre-defined & Morikwa (1994) \\
\hline $\begin{array}{l}\text { Number of } \\
\text { response }\end{array}$ & $\begin{array}{l}\text { Obtaining multiple responses is } \\
\text { difficult }\end{array}$ & $\begin{array}{l}\text { The use of repetitive questioning } \\
\text { is easily implemented }\end{array}$ & Morikwa (1994) \\
\hline Disadvantage & $\begin{array}{l}\text { Study is limited without prior } \\
\text { supply of information that had } \\
\text { already been experienced }\end{array}$ & $\begin{array}{l}\text { In some circumstances, } \\
\text { respondent's choice may not } \\
\text { represent actual behaviour in real } \\
\text { world situation }\end{array}$ & $\begin{array}{l}\text { Nyarko et al. } \\
(2015), \\
\text { Kjær (2005) }\end{array}$ \\
\hline Advantages & $\begin{array}{l}\text { Because of the observation of real } \\
\text { market behaviour, studies of this } \\
\text { nature have increasing external } \\
\text { validity } \\
\text { Low-cost evaluation }\end{array}$ & $\begin{array}{l}\text { Provides preferences and } \\
\text { information that are otherwise } \\
\text { impossible to reveal when actual } \\
\text { choice behaviour is restricted in } \\
\text { some way } \\
\text { Ensures sufficient variation in } \\
\text { data }\end{array}$ & Kjær (2005) \\
\hline
\end{tabular}

Revealed and stated preferences

Sources: Morikawa (1994), Kjær (2005) and Nyarko et al. (2015) 
apply DCE, individuals are asked to state their preferences using hypothetical scenarios (Mangham et al., 2009). The word "discrete" is indicative of a choice that is individually distinct and that it is only possible to choose one alternative from two or more alternatives. This method provides policymakers with quantitative measures of the relative significance of career attributes that impact the decision of respondents (World Health Organisation, World Bank and USAID, 2012). Figure 2 illustrates the process by which the DCE is set up and implemented.

\section{Assessment of students' job preference}

\section{Research methodology}

The research adopts empirical "quantitative methods" in the collection and analysis of data under the epistemological lens of a positivist research paradigm set within a case study strategy (Ryan and Julia, 2007; Edwards et al., 2019; Edwards et al., 2020). A deterministic analysis is then adopted using conditional logit regression for the prediction of outcomes involving job choice preference within an overarching deductive approach - where theories previously eluded upon within the literature are robustly tested (Bhattacherjee, 2012). To assist with the analysis and interpretation of data, the STATA statistical software was used. Data was collected using a Google forms' self-administered closed ended questionnaire (Owusu-Manu et al., 2020). This data collection instrument was first developed and piloted using: secondary data sourced from literature to determine the attributes and their respective levels for the development of job profiles to be used; and a focus group consisting of 15 postgraduate students who confirmed that the questionnaire was user-friendly and appropriate for the research setting. For the main survey, a cross sectional research design was used where data was collected from respondents using the closed ended questionnaire. Bhattacherjee (2012) states that the palpable benefits of the cross-sectional research design include its: strong external validity hence, data collected can be generalised to the population of the respondents; ability to capture and control a large number of variables; and capability to study a problem from different angles thus, ensuring that data is rigorously interrogated.

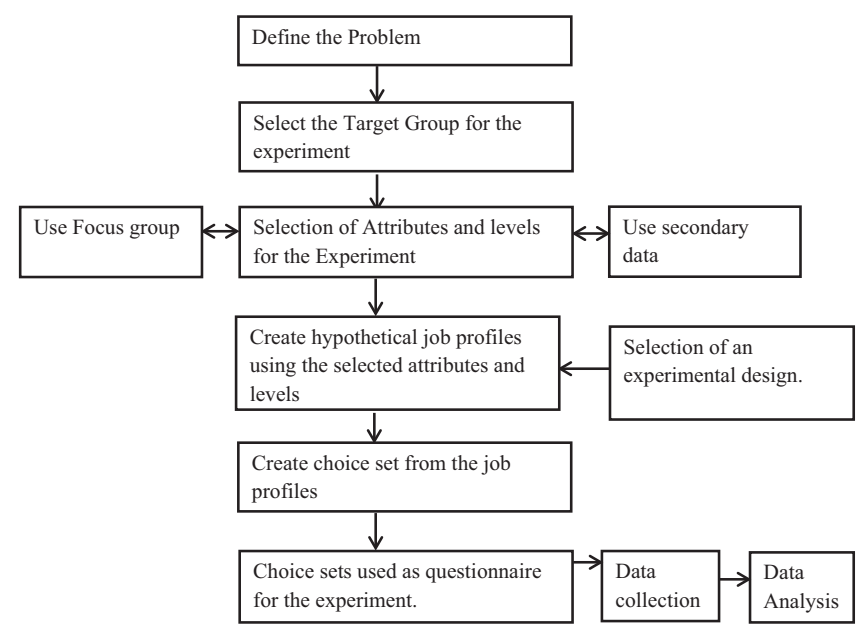

Sources: Ryan et al. (2001), Mangham (2007), Lagarde and

Blaauw (2011)

Figure 2. Framework for setting up a DCE 


\section{JHASS \\ 4,3}

\section{Population and sampling strategy}

Because of time and resource constraints, a study of the entire population of Kwame Nkrumah University of Science and Technology-Institute of Distance Learning (KNUSTIDL) postgraduate student community would be difficult. Consequently, each programme offered by the institution was considered as a stratum and respondents were selected from each strata using a stratified random sampling. In conducting a DCE, Ryan et al. (2001) suggest that using a sample size $<30$ will not yield a precise result. Orme (2010) proposed a formula, which should be used a rule of thumb in determining the minimum sample size for a DCE, namely:

$$
\mathrm{n} \geq 500 \mathrm{c} / \mathrm{ta}
$$

" $\mathrm{n}$ " is the minimum sample size or the number of respondents, " $\mathrm{t}$ " is the number of tasks (in this research, there are 28 tasks per respondents), "a" is the number of alternative per task (there are two alternative per task) and "c" is the largest number of levels for any one attribute (the salary attribute had the largest attribute of 4). Using the formula above, our sample size should not be $\leq 36$ respondents. For this study, a sample of 150 respondents was used and each respondent were presented with a 28 choice sets, each with two alternatives.

\section{Designing of the discrete choice experiment}

The DCE sought to elicit respondents' preferences using choice sets, which consist of attribute and attribute levels derived from the focus group and secondary data. Respondents were asked to choose between pairs of hypothetical job profiles. The characteristics of each job profile were the main factors that were considered to be the most influencing and affecting their career preference (Adamowicz and Louviere, 1998). Five attributes were determined to be the most important attributes that had an influence upon respondents in their selection of a job, namely, net salary; location of work; workload; supportive management; and challenging job (Table 2).

In generating the job profiles, a two-level full factorial design for the four factors (location, workload, supportive management and challenge) and a 4-level full factorial design for one factor of net salary (which is expressed mathematically as 2441 ) will generate

\begin{tabular}{|c|c|c|}
\hline Attributes & Description & Levels \\
\hline Net salary & The net monthly salary & $\begin{array}{l}\text { - GHC 3,400.00 per month } \\
\text { - GHC 3,100.00 per month } \\
\text { - GHC 2,800.00 per month } \\
\text { - GHC 2,500.00 per month }\end{array}$ \\
\hline Location & Location of the job & - City \\
\hline Workload & $\begin{array}{l}\text { Number of hours required to complete a daily } \\
\text { task after work closes }\end{array}$ & $\begin{array}{l}\text { - Works no extra hours to complete } \\
\text { task each day } \\
\text { - Works an extra hour or more to } \\
\text { complete task each day }\end{array}$ \\
\hline $\begin{array}{l}\text { Supportive } \\
\text { management } \\
\text { Challenging }\end{array}$ & $\begin{array}{l}\text { Support given to the employees by the } \\
\text { management } \\
\text { Job involves challenging task }\end{array}$ & $\begin{array}{l}\text { - Unsupportive. Management and staff } \\
\text { - Supportive management and staff } \\
\text { - Not challenging } \\
\text { - Very challenging }\end{array}$ \\
\hline
\end{tabular}

Table 2.

Attributes, description and levels managemen Challenging
Support given to the employees by the management

Job involves challenging task
- GHC 3,400.00 per month

- GHC 3,100.00 per month

2,800.00 per month

- City

task each day

- Works an extra hour or more to

- Unsupportive. Management and staff

- Supportive management and staff

- Very challenging 
64 runs of job profiles and a total of 2,016 choice sets. However, a full factorial design is cost intensive and tedious for respondents to consider all possible choice sets (Kuhfeld, 2005). Hence, the application of a fractional factorial design, which was orthogonal and balanced to reduce the number of job profiles was adopted. A design is:

- Balanced when each level occurs equally often within each factor.

- Orthogonal when every pair of levels occurs equally often across all pairs of factors (Kuhfeld, 2005).

In a DCE, each row from the designs forms an alternative, while a combination of alternatives forms a choice set. Using the orthogonal design feature in statistical package for the social scientist, the 64 runs of job profiles were reduced to 8 (refer to Table 3 ) with a total number of 28 choice sets.

The discrete choice experiment questionnaire. The research's primary quantitative data used to assess respondents' preferences were collected using the various choice sets generated after a brief introduction to the various choice sets. As suggested by Kjær (2005), it is useful to provide an example choice set in the questionnaire introduction so as to better explain the technique to the respondents before implementing the actual choice task. To elicit respondents' preferences, they were asked to make their choice for a hypothetical job. Prior to the questionnaire's administration, a pretest was undertaken to determine the degree of complexity of the experiment and also to assess data reliability and validity. For this research, validity is the ability of the DCE questionnaire to measure what it is designed to measure (the preference of respondents). To measure the research's internal or theoretical validity, respondents' choice behaviour were analysed to determine if, for example, the preference of Job 1 over Job 2 and Job 2 over Job 3 must yield a preference of Job 1 over Job 3. In total, $82 \%$ of the respondents showed evidence of transitivity in their choice behaviour during questionnaire analysis. Results from DCE were considered to be internally valid when respondents' choices conform to the rational choice theory - as defined by the axiom of transitivity and stability (Rakotonarivo, 2016). To test data reliability, the consistency of 28 choice sets with 5 attributes were analysed by observing the number of identical choices made within the different time intervals. To decrease the probability of carry-over effects, a significant time interval was used between test and retest. In evaluating the reliability using the test-retest method, the same instrument or questionnaires were used on the same sample at different time intervals (Liebe et al., 2012). The analyses of parameters in the two models (conditional logit model) then commenced at the test and retest stage to determine if there

\begin{tabular}{|c|c|c|c|c|c|}
\hline Job id & Salary & Location & Support & Challenge & Workload \\
\hline 1 & $2,500.00$ & District town & Unsupportive management & Not challenging & No extra hours \\
\hline 2 & $2,500.00$ & City & Supportive management & Very challenging & $\begin{array}{l}\text { Works more than an } \\
\text { extra hour each day }\end{array}$ \\
\hline 3 & $3,400.00$ & City & Supportive management & Not challenging & No extra hours \\
\hline 4 & $3,100.00$ & District town & Supportive management & Very challenging & No extra hours \\
\hline 5 & $2,800.00$ & District town & Supportive management & Not challenging & $\begin{array}{l}\text { Works more than an } \\
\text { extra hour each day }\end{array}$ \\
\hline 6 & $2,800.00$ & City & Unsupportive management & Very challenging & No extra hours \\
\hline 7 & $3,400.00$ & District town & Unsupportive management & Very challenging & $\begin{array}{l}\text { Works more than an } \\
\text { extra hour each day }\end{array}$ \\
\hline 8 & $3,100.00$ & City & Unsupportive management & Not challenging & $\begin{array}{l}\text { Works more than an } \\
\text { extra hour each day }\end{array}$ \\
\hline
\end{tabular}

Assessment of students' job preference 
JHASS

4,3

168

was a significance difference between the parameters. In the test-retest stage, $83 \%$ of respondents were in agreement given a reliability coefficient of $76 \%$; such a coefficient value (based on kappa statistics coefficient between $61 \%$ to $80 \%$ ) showed substantial reliability of the survey instrument.

Data collection. Data from respondents were collected using a combination of selfadministered close-ended questionnaires and a computer-based data collection method. During the self-administered or face-to-face technique, the enumerator explained any difficulties encountered in the questionnaire completion. In the computer-based data collection method, email addresses of respondents were used to deliver the questionnaires for eliciting respondents' preferences. Data collected was then entered and organised into a spread sheet and later imported into STATA for further analysis using the conditional logit function estimate to determine the probability of choosing a job profile (Job A) when the alternative (Job B) is held constant.

The model. Responses observed were used as the dependent variable while those attributes that were varied in the survey were considered as independent variables. Thus, if a job in a particular choice set is selected, it can be said that the probability or utility in preferring a job over its alternative in the choice set is greater. The model adopted for this study is based on the random utility theory, which is given mathematically as Prob ( $\mathrm{Y}=$ $1 \mid \mathrm{X})=\operatorname{Prob}\left(\mathrm{U}_{\mathrm{jobA}}>\mathrm{U}_{\mathrm{jobB}}\right)$ with the assumption that the utility associated with every job depends on the attribute and attribute level. The linear and additive model used for this experiment is:

$$
\begin{aligned}
\mathrm{P}[\mathrm{Y}=1 \mid \mathrm{X}]= & \beta_{0}+\beta_{1} \mathrm{~S}_{1}+\beta_{2} \mathrm{~S}_{2}+\beta_{3} \mathrm{~S}_{3}+\beta_{4} \mathrm{~S}_{4}+\beta_{5} \mathrm{Lo}_{\mathrm{d}}+\beta_{6} \mathrm{Lo}_{\mathrm{c}}+\beta_{7} \mathrm{Wk}_{\mathrm{et}} \\
& +\beta_{8} \mathrm{Wk}_{\mathrm{nt}}+\beta_{9} \mathrm{~S}_{\mathrm{un}}+\beta_{10} \mathrm{~S}_{\mathrm{su}}+\beta_{11} \mathrm{C}_{\mathrm{y}}+\beta_{12} \mathrm{C}_{\mathrm{n}}+\varepsilon
\end{aligned}
$$

where:

$\mathrm{Y}=$ dependent variable (choice), which is 1 when Job $\mathrm{A}$ is taken and 0 otherwise;

$\beta_{\mathrm{i}} \quad=$ coefficient or constant for the alternatives (where I = 1,2,3,4 . .0.12);

$\mathrm{S}_{1} \quad=$ net monthly salary of GHC 2,500.00;

$\mathrm{S}_{2} \quad$ = net monthly salary of GHC 2,800.00;

$\mathrm{S}_{3} \quad=$ net monthly salary of GHC 3,100.00;

$\mathrm{S}_{4} \quad=$ net monthly salary of GHC 3,400.00;

$\mathrm{Lo}_{\mathrm{d}}=$ job located in district town;

$\mathrm{Lo}_{\mathrm{c}}=$ job located in city;

$\mathrm{Wk}_{\text {et }}=$ work an extra hour;

$\mathrm{Wk}_{\mathrm{nt}}=$ works no extra hour;

$\mathrm{S}_{\mathrm{un}}=$ unsupportive management;

$\mathrm{S}_{\mathrm{su}}=$ supportive management;

$\mathrm{C}_{\mathrm{y}} \quad$ = very challenging;

$\mathrm{C}_{\mathrm{n}} \quad$ = not challenging; and

$\varepsilon \quad=$ error term.

\section{Discussion of results}

A total number of 128 respondents from a sample frame of 150 completed the questionnaire representing an $85.33 \%$ response rate. These respondents consisted of 69 men and 59 women thus, representing $54 \%$ and $46 \%$ of the total sample size, respectively. This sample also broadly concurs with information from the Ghana Statistical Service (2015), which 
suggests that the proportion of men who studied higher education qualifications was higher than women. Table 4 shows descriptive statistics of participating respondents.

Regard employment, 112 respondents were employed while 16 respondents were unemployed and this represented $87.5 \%$ and $12.5 \%$ of the total sample size, respectively. The percentage of unemployed individuals used for the research was higher than the unemployment rate $(11.90 \%)$ recorded in 2015 and lower than the all-time high $12.90 \%$ recorded in 2005 (Ghana Statistical Service, 2015). Out of the 112 respondents' students who were employed, $71.9 \%$ occupied non-managerial positions while $28.1 \%$ occupied various managerial positions.

\section{Modelling the job preference}

In modelling the respondents' job preference, the impact or utility (increasing or decreasing) of the various attributes and their respective levels (refer back to Table 2) were analysed. The attribute salary was considered as a continuous variable while other non-monetary variables were coded as dummy variables. Prior to the analysis of the respondents' preference model, tests for multicollinearity within attributes and their respective levels was conducted. In a DCE, the effect of these highly collinear variables or attributes obscures the identification of predictor variables that have an effect on the preferences of individuals (World health Organisation, World Bank and USAID, 2012). Consequently, the following variables were excluded from the analysis due to the existence of multicollinearity: salary of GHC 2,500.00; job located in district; works an extra hour; no challenge; and unsupportive management.

To assess and model the preference of respondents, conditional logit was adopted, which is appropriate for estimating choice behaviour models. Conditional logit is well-suited for choice experiments where the characteristics that make up an alternative are of interest to the researcher rather than the characteristics of the respondent making the choice (Hoffman et al., 1988). For this research, the preference of a job alternative in each choice set is defined by its attribute and their respective levels. Table 5 presents estimates used in modelling respondents' job preferences. The preference of a job alternative considered as the outcome variable was dependent on the following independent variables: salary (GHC 2,800.00, GHC 3,100.00 and GHC 3,400.00); no extra hours; job located in the city; supportive management; and a very challenging job.

The analysis results show that the model as a whole was significant with a $p$-value of 0.000. This implies that at least one of the regression coefficients (Beta) is not equal to zero - therefore, the model fits significantly better than a model with no independent variables. The analysis also reveals that all the coefficients for the attributes were significant at the 95\% confidence level except for "workload of no extra hours", which was not significant.

\begin{tabular}{lrrrrrr}
$\begin{array}{l}\text { Age group } \\
\text { (years) }\end{array}$ & Male & $(\%)$ & Female & $(\%)$ & Total & $(\%)$ \\
\hline $24-29$ & 38 & 30 & 36 & 28 & 74 & 58 \\
$30-37$ & 26 & 20 & 20 & 16 & 46 & 36 \\
$38-45$ & 2 & 2 & 2 & 2 & 4 & 3 \\
$45+$ & 3 & 2 & 1 & 1 & 4 & 3 \\
Total & 69 & 54 & 59 & 46 & 128 & 100
\end{tabular}

\section{Assessment of students' job preference}

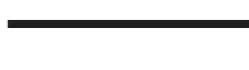




\section{JHASS 4,3}

Attributes
Salary (relative to GHC 2,500)
GHC 2,800.00

GHC 3,100.00

GHC 3,400.00

170

No extra hours (relative to extra working hours)

Table 5.

City (relative to district town)

Empirical model

based on

respondents'

preference (main

model)

Supportive management

(relative to non-support)

Very challenging (relative to

no challenge)

Constant

Beta

Coefficients

Standard error

Z $\quad P>|Z|$

Notes: NB: Number of respondents $=128 ;$ prob $>$ chi square $=0.0000$

A positive sign of the beta coefficient implies an increase in utility of preferring a job alternative over another, while a negative coefficient means a decrease in preference utility. Thus, a positive sign signifies respondents' interest in one attribute over the alternative, while a negative sign denotes otherwise (Lyu, 2020). From Table 5, the following attributes: supportive management; job in city; salary in the range (GHS 2,800 to GHS 3,400); and very challenging job had a positive impact on respondents' preference for a job relative to their alternative - thereby increasing their utility to take the job. Hence, job located in the city relative to one located in a district town increased the utility of respondents' accepting the job by 0.324042 . This was not surprising considering the high perception of opportunities available to individuals living in a city vis-à-vis district town. To increase job preference located in a district town, Kolstad (2010) suggested that there should be room for increase in salary or allowance given to individuals who are posted in these areas. Again, results from the model shows that the utility of respondents increased from 0.524 to 1.282 with an increasing salary level (GHS 2,800.00 to GHS 3,400). For example, an increase of GHS 1 in the respondents' salary (GHS 3,400) will increase their utility by 1.282 times the resulting increase. Hence, increased salary should have a positive impact on the retention of postgraduate students of KNUST-IDL.

Regard the attribute "challenge", the respondents' preferences were positively affected by very challenging jobs and the utility of postgraduate students increased by 0.4926365 relative to a job that is not challenging. Perhaps, a mental challenge is one reason why students study on a postgraduate award in the first instance - future work is required to explain this observed phenomena. Curiously, "workload of no extra hours" decreased the utility of respondents' job preference and as such, had a negative impact upon their job preference. This result agreed with Demel et al. (2019), who found that a flexible job schedule had a negative impact on the preferences of postgraduate students. The authors (Demel et al., 2019) opined that there are expectations for graduates to work long hours in their new jobs hence, the negative impact.

Though there are some limitations that are unavoidable in conducting a DCE (such as respondents not taking the research seriously when completing their responses), it was evident that the experiment was able to simulate a real world situation. By applying the DCE, attributes that had a significant and positive impact upon the career choice preference of respondents were consistent with theory (for example, increase in salary 
having an effect on increasing utility) and previous literature (Doiron et al., 2014; Mangham, 2007).

\section{Investigating gender differences in the preference of a job}

Table 6 presents parameter estimate outputs for male and female postgraduate students. The estimates were used to assess the relative impact of each attribute and attribute level on their job preference.

The model produced for male respondents fits significantly better than a model with no predictors. With the exception of no extra hours, which had an insignificant effect upon the choice preference of a job, all estimates of the coefficient had a positive impact upon the respondents' choice thereby increasing their utility of choosing a job over an alternate one. The key attributes of supportive management, job located in the city, a challenging job and salary increased the utility of the male respondents' preferences of a career or a job. For instance, the uptake for a job located in the city, and with a salary of GHC 3,400.00, increased the utility of male respondents by 0.2770092 and 1.293559 , respectively - relative to a job located in a district town with a net monthly salary of GHC 2,500.00. Again jobs that are very challenging also had a positive impact on the male respondents' preference thereby increasing their probability uptake by 0.5142833 - compared to a job, which was not challenging. Consequently, the model for male respondents revealed that the coefficients signs of attributes were the same as the main model indicating a similar impact (with varying utility) on job preference.

From Table 6 above, the model for female respondents was also significant at the 95\% confidence level. Again with the exception of "job with no extra hours", which was not significant, all other attribute levels were considered significant, and thus, had a positive impact on female respondents' job preference. It was expected that "job with no extra hours" might have had a positive impact on female respondents' preference because of their predilection towards securing a flexible working schedule (Chusmir and Parker, 1991). However, this was not apparent as seen from the coefficient $\left(\beta_{4}=-0.2043216\right)$, which

\begin{tabular}{lccccc}
\hline Attributes & Betas & Coefficients & Standard error & $Z$ & $P>|Z|$ \\
\hline Male respondents & & & & & \\
Salary (relative to GHC 2,500) & & & & & \\
GHC 2,800.00 & $\beta_{1}$ & 0.4468581 & 0.1878952 & 2.38 & 0.017 \\
GHC 3,100.00 & $\beta_{2}$ & 1.127863 & 0.2076921 & 5.43 & 0.000 \\
GHC 3,400.00 & $\beta_{3}$ & 1.293559 & 0.180143 & 7.18 & 0.000 \\
No extra hours(relative to extra working hours) & $\beta_{4}$ & -0.0291378 & 0.1082699 & -0.27 & 0.788 \\
City (relative to district town) & $\beta_{5}$ & 0.2770092 & 0.0921165 & 3.01 & 0.003 \\
Supportive management (relative to non-support) & $\beta_{6}$ & 0.8461281 & 0.1199821 & 7.05 & 0.000 \\
Very challenging (relative to no challenge) & $\beta_{7}$ & 0.5142833 & 0.0978014 & 5.26 & 0.000 \\
Constant & $\mathrm{B}_{0}$ & 0.0538476 & 0.1343182 & 0.40 & 0.688 \\
Female respondents & & & & & \\
Salary (relative to GHC 2,500.00) & & & & & \\
GHC 2,800.00 & $\beta_{1}$ & 0.6292762 & 0.2217101 & 2.84 & 0.005 \\
GHC 3,100.00 & $\beta_{2}$ & 1.204843 & 0.2405376 & 5.01 & 0.000 \\
GHC 3,400.00 & $\beta_{3}$ & 1.264987 & 0.2128265 & 5.94 & 0.000 \\
No extra hours (relative to extra working hours) & $\beta_{4}$ & -0.2043216 & 0.126972 & -1.61 & 0.108 \\
City (relative to district town) & $\beta_{5}$ & 0.3939604 & 0.1097845 & 3.59 & 0.000 \\
Supportive management (relative to non-support) & $\beta_{6}$ & 0.4856573 & 0.136635 & 3.55 & 0.000 \\
Very challenging (relative to no challenge) & $\beta_{7}$ & 0.4628911 & 0.1157794 & 4.00 & 0.000 \\
Constant & $\mathrm{B}_{0}$ & 0.3502879 & 0.1552331 & 2.26 & 0.024 \\
\hline & & & & & Parameter estimates \\
\hline
\end{tabular}

Assessment of students' job preference

\section{$+2$}


JHASS
4,3

showed a decreasing utility relative to working an extra hour. This negative impact on female respondents' preference might be attributed to respondents not considering this attribute level (no extra hours) during the trade-off between options available.

How supportive the management of a job is, relative to an unsupportive management, increased the utility associated with a female's career choice by 0.4856573 . The model for female respondents as a whole was significant at $95 \%$ confidence, and hence, there were no significant differences in the model for male and female postgraduate students. Though the attribute levels had the same impact (same coefficient sign) on the job preference for both male and female respondents, from the two models it was evident that male and female utility for job vary with regard to the various job attributes. For instance, the utility of female respondents preferring a job in the city increased by 0.3939604 while male respondents increased by 0.2770092 .

In regard to the theory of gender role socialisation, Barbulescu and Bidwell (2013) in assessing why men and women choose different jobs concluded that male and female students rated the value of money in relation to a job differently. Specifically, the authors (Barbulescu and Bidwell, 2013) stated that female students were less likely to value money in their choice of a job when compared to male students. This assertion made concurs with the findings presented in Tables 5 and 6 where the utility for a job with a salary GHC 3,400.00 increased by 1.264 for female respondents while that of male respondents increased by 1.294.

\section{Ranking of attributes based on their impact on respondents preferences}

The impact of attributes and their respective levels used for the study were analysed and ranked to determine their relative importance in respondents' job preference. According to Mangham and Hanson (2008), this order is achieved by calculating the ratio of the coefficient of a non-monetary attribute to that of a net monthly salary (for example, GHC 2,800.00). A rank of 1 indicates the attribute, which had the most impact on postgraduates' job preference while 8 indicates the least impact. The results are shown in Table 7.

Results from Table 7 reveal that the salary of GHC 3,400.00 had the highest impact (ranked 1) on the job preference of postgraduate distance learning students. This result concurs with the research of Mangham and Hanson (2008) where the highest monthly pay had the most significant impact on the respondents' choice of job. Aside from salary being a motivating factor in job preference, there are other non-monetary attributes, which must be considered during the retention and recruitment process of postgraduate students. Amongst these attributes was a job with supportive management, which was seen to have a positive impact on the preference of a job, and hence, ranked higher than a salary of GHS 2,800.00. However, as workload was not considered as significant by respondents' job preference, it would be prudent for policymakers not to assign more resources to this attribute.

Table 7.

Relative importance of career attributes on respondents' preferences

\begin{tabular}{lccc}
\hline & $\begin{array}{c}\text { Magnitude of } \\
\text { Predictor variables }\end{array}$ & $\begin{array}{c}\text { Ratio relative to net } \\
\text { monthly salary GHC 2,800 }\end{array}$ & Rank \\
\hline Net salary GHC 3,400.00 & 1.2822590 & 2.44251254 & 1 \\
Net salary GHC 3,100.00 & 1.1633400 & 2.21598955 & 2 \\
Supportive management & 0.6928615 & 1.31979803 & 3 \\
Net salary GHC 2,800.00 & 0.5249754 & 1 & 5 \\
Challenge (very) & 0.4926365 & 0.93839921 & 6 \\
Location (city) & 0.3240423 & 0.61725235 & 7 \\
No extra hours to work & 0.1033793 & 0.19692218 & \\
\hline
\end{tabular}


Studies on DCEs have been extensively used in developed countries with few studies applying this approach in developing countries - primarily, due to the cost involved at the data collection stage and also a lack of experience with this survey method (Nguyen $e t$ al., 2015). Hence, this study is the amongst the first to employ the use of a DCE and electronic self-administered closed ended questionnaires to elicit job preferences from postgraduate students in the developing country of Ghana. This novel approach secured a high response level from participants. The knowledge contribution also proved that jobs with no extra hours of workload were not considered to be significant for both male and female postgraduate students - this claim challenges the assertion made by Chusmir and Parker (1991) that flexible working hours had a significant effect on female job preference. This finding will require additional future research to further elucidate upon the reasons for this apparent anomaly. It was also evident that a postgraduate student's job preference was greatly influenced by how challenging the job is relative to a non-challenging job. This phenomenon may be attributed to postgraduate students' desire to further the boundaries of knowledge to secure a better position or rapid promotion by generating innovative ideas and the application of new knowledge acquired from their various programmes. The study revealed that a job with a net salary (GHC 2,800.00, GHC 3,100.00 and GHC 3,400.00), supportive management, very challenging and located in the city had a positive impact or played a role in the respondents' job preference decision making. Surprisingly, a job with no extra hours after work had a negative impact upon the choice of respondents. This phenomenon could be attributed to respondents not considering workload to be a major influencing factor in their job preference or may be due to heterogeneity in preferences. The research also examined whether the respondents' gender impacted upon their job preference. From the two models produced, all the significant factors in the segmented models were in accordance with the main model thus, no significance difference in the job preference by male and female students was apparent. This may be attributed to the fact that in modern Ghana (and particularly amongst the younger generations), equality between genders is apparent. Although employers cannot provide prospective employees with all their preferences, the research findings give employers invaluable foresight of the various preferences of postgraduate students that can increase their retention rates, attract the best talent and reduce the staff turnover rate of organisations. Employers of jobs that cannot provide higher salaries can compensate employees with other non-monetary attributes or increase salaries to cater for the absence of some preferred non-monetary attributes. Not all these conditions may be realised, particularly, as not all jobs are located in a city nevertheless, the results do provide invaluable indicators that can be used to ensure that jobs offered are more attractive. Adopting the DCE in eliciting preferences of prospect and current employees can aid organisations in making of $\mathrm{HR}$ policies that can attract the best candidate and also make their organisation more competitive.

Three primary recommendations stem from this research for policymakers, employers and recruitment organisations. Firstly, salary is an important factor that should not be overlooked during employment of postgraduate students. Hence, postgraduate students who are posted to district towns (which had a negative impact upon the job preference) should be compensated with high salaries as suggested by Lagarde and Blaauw (2011). Secondly, policies, which promote supportive management at workplaces should be implemented to increase the retention rate of postgraduate students. Consequently, job attributes that make a position attractive to postgraduate students should be tailor made to their needs and preferences. Third, policymakers should adopt quantitative methodologies (vis-à-vis subjective judgement) for 
JHASS

4,3

eliciting the preferences of their employees. This will help in determining robust and appropriate policy options that impact upon job turnover and retention.

However, further research is again required to further examine and expand upon this initial finding.

\section{Conclusions and recommendations}

The DCE adopted for this study helped to construct a wider range of hypothetical job alternatives than would otherwise be possible and revealed postgraduate employment preferences. The attributes that had the greatest impact upon career choice preferences of the postgraduate students of KNUST-IDL in order of importance were: salary of GHC 3,400.00, salary of GHC 3,100.00; supportive management; salary of GHC 2,800.00; very challenging job; job located in the city; and no extra working hours. The inclusion of salary was in line with prior expectation and economic theory, which suggests that the higher the salary, the higher the utility associated with it. Hence, it was found in the study that an increase in salary (from GHC 2,800.00 to GHC 3,400.00) increased the utility of postgraduate students. Aside from salary, which had the greatest impact on career choice, supportive management also played an important role in the postgraduate students' job preferences. The high preference for supportive management was in line with the findings of Doiron et al. (2014).

An issue for further study is the need to expand the scope of work undertaken to include postgraduate students from different generational cohorts and other institutions within Ghana, as well as other similar developing nations. Such a study will seek to further elucidate upon students employment preferences within prescriptive guidance for employers and policymakers as a practical and impactful product of this work.

\section{References}

Adamowicz, W. and Louviere, J. (1998), "Introduction to attribute-based stated choice methods", Alternatives, Vol. 105, available at: http://citeseerx.ist.psu.edu/viewdoc/download?doi=10.1.1.119.6910\& rep=rep1\&type $=$ pdf

Aghimien, D.O., Aigbavboa, C., Edwards, D.J., Mahamadu, A.-M., Olomolaiye, P., Onyia, M. and Nash, H. (2020), "A fuzzy synthetic evaluation of the challenges of smart city development in developing countries", Smart and Sustainable Built Environment, available at: https://doi.org/ 10.1108/SASBE-06-2020-0092

Agyeman, C.M., District, K. and Nadu, T. (2014), "Employee demographic characteristics and their effects on turnover and retention in MSMEs", International Journal of Recent Advances in Organizational Behavior and Decision Sciences, Vol. 1 No. 1, pp. 12-29.

Arokiasamy, A.R.A. (2013), "A qualitative study on causes and effects of employee turnover in the private sector in Malaysia”, Middle East Journal of Scientific Research, Vol. 16 No. 11, pp. 1532-1541.

Ball, J. (2003), “Understanding Herzberg's motivation theory”, available at: www.chinaacc.com/upload/ html/2013/06/26/lixingcun841e7885772f4e7f907bf6272b185c41.pdf

Bandura, A. (1978), "Social learning theory of aggression”, Journal of Communication, Vol. 28 No. 3, pp. $12-29$.

Barbulescu, R. and Bidwell, M. (2013), "Do women choose different jobs from men? Mechanisms of application segregation in the market for managerial workers", Organization Science, Vol. 24 No. 3, pp. 737-756.

Bhattacherjee, A. (2012), "Social science research: principles, methods, and practices", available at: http://scholarcommons.usf.edu/oa_textbooks 
Booth, S. and Hamer, K. (2007), "Labour turnover in the retail industry: predicting the role of individual, organizational and environmental factors labour turnover in the retail industry", International Journal of Retail and Distribution Management, Vol. 35 No. 4, pp. 289-307.

Chusmir, L.H. and Parker, B. (1991), "Gender and situational differences in managers' values: a look at work and home live”, Journal of Business Research, Vol. 23 No. 4, pp. 325-335.

Clark, M.D., Determann, D., Petrou, S., Moro, D. and de Bekker-Grob, E.W. (2014), "Discrete choice experiments in health economics: a review of the literature", PharmacoEconomics, Vol. 32 No. 9, pp. 883-902, available at: $\mathrm{https} / / / \mathrm{doi} .0 \mathrm{rg} / 10.1007 /$ s40273-014-0170-x

Demel, S., Mariel, P. and Meyerhoff, J. (2019), "Job preferences of business and economics students", International Journal of Manpower, Vol. 40 No. 3, pp. 473-499, available at: https://doi.org/ 10.1108/IJM-09-2017-0249

Doiron, D., Hall, J., Kenny, P. and Street, D.J. (2014), "Job preferences of students and new graduates in nursing", Applied Economics, Vol. 46 No. 9, pp. 924-939.

Edwards, D.J., Pärn, E.A., Love, P.E.D. and El-Gohary, H. (2017), "Machinery, manumission and economic machinations", Journal of Business Research, Vol. 70, pp. 391-394, available at: http:// dx.doi.org/10.1016/j.jbusres.2016.08.012

Edwards, K. and Quinter, M. (2011), "Factors influencing students career choices among secondary school students in Kisumu municipality, Kenya”, Journal of Emerging Trends in Educational Research and Policy Studies, Vol. 2 No. 2, pp. 81-87.

Edwards, D.J., Pärn, E.A., Sing, C.P. and Thwala, W.D. (2019), "Risk of excavators overturning: determining horizontal centrifugal force when slewing freely suspended loads", Engineering, Construction and Architectural Management, Vol. 26 No. 3, pp. 479-498, available at: https://doi. org/10.1108/ECAM-03-2018-0125

Edwards, D.J., Rillie, I., Chileshe, N., Lai, J., Hossieni, M.R. and Thwala, W.D. (2020), “A field survey of hand-arm vibration exposure in the UK utilities sector", Engineering, Construction and Architectural Management, Vol. 27 No. 9, available at: https://doi.org/10.1108/ECAM-09-2019-0518

Gallie, D., Felstead, A. and Green, F. (2012), "Job preferences and the intrinsic quality of work: the changing attitudes of British employees 1992-2006”, Work, Employment and Society, Vol. 26 No. 5, pp. 806-821, available at: https://doi.org/10.1177/0950017012451633

Ghapanchi, A.H. and Aurum, A. (2011), "Antecedents to IT personnel's intentions to leave: a systematic literature review", Journal of Systems and Software, Vol. 84 No. 2, pp. 238-249, available at: http://dx.doi.org/10.1016/j.jss.2010.09.022

Ghana Statistical Service (2015), Ghana Living Standards Survey Report, available at: www.statsghana. gov.gh/docfiles/glss5_report.pdf

Hoffman, S.D., Duncan, G.J. and Arbor, A. (1988), "Multinomial and conditional logit discrete-choice models in demography", Demography, Vol. 25 No. 3, pp. 415-427.

Kjær, T. (2005), "A review of the discrete choice experiment - with emphasis on its application in health care”, University of Southern Denmark, pp. 1-139.

Kolstad, J.R. (2010), What Affects the Career Choices of Health Workers?, University of Bergen Bergen.

Kossivi, B., Xu, M. and Kalgora, B. (2016), "Study on determining factors of employee retention”, Open Journal of Social Sciences, Vol. 04 No. 5, pp. 261-268.

Kretchmar, J. (2009), “Gender socialization”, available at: http://vidaka.home.mruni.eu/wp-content/ uploads/2009/09/gendsoci.pdf (accessed 1 April 2017).

Kuhfeld, W. (2005), "Experimental design, efficiency, coding, and choice designs", Marketing Research Methods in SAS, available at: http://scholar.google.com/scholar?hl=en\&btnG=Search\&q= intitle:Experimental+Design $+:+$ Efficiency,++ Coding,++ and + Choice+Designs $\# 0$

Lagarde, M. and Blaauw, D. (2011), "Using stated choice preferences to investigate job preferences and migration patterns of South African nurses", Norface Migration Network Conference on 


\section{JHASS 4,3}

"Migration: Economic Change, Social Challenge", available at: https://cream.conferenceservices. net/resources/952/2371/pdf/MECSC2011_0310_paper.pdf

Lancaster, K.J. (1966), "A new approach to consumer theory”, Journal of Political Economy, Vol. 74 No. 2, pp. 132-157.

Liebe, U., Meyerhoff, J. and Hartje, V. (2012), "Test - retest reliability of choice experiments in environmental valuation", pp. 389-407.

Louviere, J.J., Flynn, T.N. and Carson, R.T. (2010), "Discrete choice experiments are not conjoint analysis", Journal of Choice Modelling, Vol. 3 No. 3, pp. 57-72.

Lyu, S.O. (2020), "Applying discrete choice models to understand sport tourists' heterogeneous preferences for winter Olympic travel products", Tourism Economics, available at: https://doi. org/10.1177/1354816619899222

McFadden, D. (1974), "Conditional logit analysis of qualitative choice behavior", Frontiers in Econometrics, New York Academic Press, pp. 105-142.

Mangham, L. (2007), Addressing the Human Resource Crisis in Malawi's Health Sector: Employment Preferences of Public Sector Registered Nurses, (Issue March).

Mangham, L.J. and Hanson, K. (2008), "Employment preferences of public sector nurses in Malawi: results from a discrete choice experiment", Tropical Medicine and International Health, Vol. 13 No. 12, pp. 1433-1441.

Mangham, L.J., Hanson, K. and McPake, B. (2009), "How to do (or not to do). . .designing a discrete choice experiment for application in a low-income country", Health Policy and Planning, Vol. 24 No. 2, pp. 151-158, available at: https://doi.org/10.1093/heapol/czn047

Morikawa, T. (1994), "Correcting state dependence and serial correlation in the RP/SP combined estimation method", Transportation, Vol. 21, pp. 153-165, available at: https://doi.org/10.1007/BF01098790

Newman, C., Edwards, D.J., Martek, I., Lai, J. and Thwala, W.D. (2020), "Industry 4.0 deployment in the construction industry: a bibliometric literature review and UK-based case study", Smart and Sustainable Built Environment, Vol. ahead-of-print No. ahead-of-print, available at: https://doi. org/10.1108/SASBE-02-2020-0016

Nguyen, T.C., Robinson, J., Whitty, J.A., Kaneko, S. and Chinh, N.T. (2015), “Attribute non-attendance in discrete choice experiments: a case study in a developing country”, pp. 22-33.

Nishimura, H., Ok, E.A. and Quah, J.K.H. (2016), "A comprehensive approach to revealed preference theory", pp. 1-33.

Nwogu, G.A. and Momoh, A.M. (2015), "Graduate employability qualities and personality preference as determinants of job performance in Nigeria", European Scientific Journal, Vol. 11 No. 25, pp. 241-250.

Nyarko, E., Baidoo, I. and Doku-Amponsah, K. (2015), Application of Discrete Choice Experiment in Bus Transport, Lambert Academic Publishing, Saarbrücken, pp. 1-82.

Olamide, S.O. and Oluwaseun, S. (2013), "The factors determining the choice of career among secondary school students", International Journal of Engineering Science, Vol. 2 No. 6, pp. 33-44.

Orme, B.K. (2010), Getting Started with Conjoint Analysis: Strategies for Product Design and Pricing Research, Second ed., Research Publishers LLC Madison, Wisc.

Owusu-Manu, D., Adjei, T.K., Sackey, D.M., Edwards, D.J. and Hosseini, R.M. (2020), "Mainstreaming sustainable development goals in Ghana's energy sector within the framework of public-private partnerships: challenges, opportunities and strategies", Journal of Engineering, Design and Technology, Vol. ahead-of-print No. ahead-of-print, available at: https://doi.org/10.1108/JEDT-06-2020-0255

Owusu-Manu, D., Jehuri, A., Edwards, D.J., Boateng, F. and Asumadu, G. (2019), "The impact of infrastructure development on economic growth in sub-Saharan Africa with special focus on Ghana", Journal of Financial Management of Property and Construction, Vol. 24 No. 3, pp. 253-273, available at: https://doi.org/10.1108/JFMPC-09-2018-0050

Raghavarao, D., Wiley, J.B. and Chitturi, P. (2011), “Choice based conjoint analysis”, Models and Designs. 
Rakotonarivo, O.S., Schaafsma, M. and Hockley, N. (2016), “A systematic review of the reliability and validity of discrete choice experiments in valuing non-market environmental goods", Journal of Environmental Management, Vol. 183, pp. 98-109.

Rehman, S. (2012), "Employee turnover and retention strategies: an empirical study of public sector organizations of Pakistan", Global Journal of Management and Business Research, Vol. 12 No. 1, pp. 83-89.

Roberts, C.J., Pärn, E.A., Edwards, D.J. and Aigbavboa, C. (2018), "Digitalising asset management: concomitant benefits and persistent challenges", International Journal of Building Pathology and Adaptation, Vol. 36 No. 2, pp. 152-173, doi: 10.1108/IJBPA-09-2017-0036.

Ryan, M.J. and Julia, M.B. (2007), "The symbiotic nature of hermeneutical vs. classical generated knowledge".

Ryan, M., Bate, A., Eastmond, C.J. and Ludbrook, A. (2001), "Use of discrete choice experiments to elicit preferences", Quality in Health Care, Vol. 10 (Suppl I), pp. i55-i60, doi: 10.1136/qhc.0100055.

Sibson, R. (2011), "Career choice perceptions of undergraduate event, sport and recreation management students: Australian case study", The Journal of Hospitality Leisure Sport and Tourism, Vol. 10 No. 2, pp. 50-60.

Stebleton, M.J. (2007), "Career counseling with African immigrant colleges: theoretical approaches and implications for practice", The Career Development Quarterly, Vol. 55 No. 4, pp. 290-312.

Vooren, M., Haelermans, C., Groot, W. and Maassen van den Brink, H. (2019), "Employers' preferences for IT-retrainees: evidence from a discrete choice experiment", International Journal of Manpower, Vol. 40 No. 7, pp. 1273-1287, available at: https://doi.org/10.1108/IJM-01-2019-0001

World health Organisation, World Bank and USAID (2012), "How to conduct a discrete choice experiment for health workforce", World Health Organisation, available at: http://medcontent. metapress.com/index/A65RM03P4874243N.pdf

York Health Economics Consortium (2016), Discrete Choice Experiment (DCE), World Health Organisation, available at: https://yhec.co.uk/glossary/discrete-choice-experiment-dce/

\section{Further reading}

Abley, J. (2000), "Stated preference techniques and consumer decision making: new challenges to old assumptions", Cranfield School of Management, available at: https:/doi.org/10.3354/meps10443

Aliyu, A.A., Bello, M.U., Kasim, R. and Martin, D. (2014), "Positivist and non-positivist paradigm in social science research: conflicting paradigms or perfect partners", Journal of Management and Sustainability, Vol. 4 No. 3, pp. 79-95.

Baltas, G. and Doyle, P. (2001), "Random utility models in marketing research: a survey", Journal of Business Research, Vol. 51 No. 2, pp. 115-125.

Bredolt, P. and Lundahl, S. (2008), Graduate Students' Preferences in First Employment Attributes, Jonkoping University, Jonkoping.

Chow, I.H.S. and Ngo, H. (2002), "Gender differences in job choice of university students in China", Journal of Applied Business Research, Vol. 18 No. 2, pp. 15-26.

Crowther, D. and Lancaster, G. (2008), Research Methods: A Concise Introduction to Research in Management and Business Consultancy, Butterworth-Heinemann, Oxford.

Damaraju, R., James, W.B. and Pallavi, C. (2011), Choice-Based Conjoint Analysis, Models and Designs, CRC Press: Taylor and Francis Group, London New York, NY.

Dagsvik, J.K. (2004), "Random utility models for discrete choice behavior an introduction".

Dash, N.K. (2005), "Selection of the research paradigm and methodology", www.celt.mmu.ac.uk/ researchmethods/Modules/Selection_of_methodology/ (accessed 24 June 2017).

Deluna, R. and Berdos, K. (2015), "Factors affecting length of job search and job switching in Davao city".

Discrete Choice Experiment (DCE) (2016), "York; York health economics consortium”, available at: www.yhec.co.uk/glossary/discrete-choice-experiment-dce/ 
JHASS 4,3

Flowers, P. (2009), "Research philosophies - importance and relevance", Leading Learning and Change, Vol. 1 No. 3, pp. 1-5.

Hytter, A. (2007), "Retention strategies in France and Sweden", The Irish Journal of Management, Vol. 28 No. 1, pp. 59-79.

Jansen, S., Coolen, H. and Goetgeluk, R. (2011), The Measurement and Analysis of Housing Preference and Choice, Springer Press, London New York, NY.

Kankam, G. and Onivehu, A. (2000), "Principles and practice of guidance and counselling", Unpublished. University of Cape Coast.

Kian, T.S., Fauziah, W. and Yusoff, W. (2012), "Generation x and y and their work motivation", University Tun Hussein Onn Malaysia, pp. 396-408.

Lombardo (2020), "Consumer preferences and choice in economics", available at: http://study.com/ academy/lesson/consumer-preferences-choice-in-economics.html (accessed 27 March 2017).

Lourdes, S., Jose, R.P., Sandra, I., Maria, J.B., Alvaro, E., Angela, G., Marisa, A. and Euginio, A.P. (2011), "Generation or culture? Work attitude drivers: an analysis in Latin America and Iberian countries", Working Paper No. 919, University of Navarra.

Louviere, J.J., Hensher, D.A. and Swait, J.D. (2000), "Stated choice methods: analysis and application", Cambridge University Press, available at: https://doi.org/10.1002/jae.701

McLeod, S.A. (2016), "Bandura - social learning theory", available at: www.simplypsychology.org/ bandura.html

Prempeh, M. (2014), "Factors accounting for labour turnover in the hospitality industry in Sunyani municipality, Ghana", African Journal of Hospitality, Tourism and Leisure, Vol. 4 No. 2, pp. 1-14.

Rao, K. and Kumar, M. (2003), "Discrete choice models for location and travel in the context of developing countries", Journal of European Transport Trasporti Europei, Vol. 23, pp. 20-29.

Researchgate (2020), "Paul Samuelsson and revealed preference theory", available at: www.researchgate. net/publication/228247551_Paul_Samuelson_and_Revealed_Preference_Theory (accessed 29 March 2017).

Tolbize, A. (2008), "Generational differences in the workplace”, available at: http://rtc.umn.edu/docs/ 2_18_Gen_diff_workplace.pdf (accessed 22 March 2017).

Wade Hands, D. (2014), "Paul Samuelsson and revealed preference theory", History of Political Economy, Vol. 46 No. 1, pp. 1-35.

Wharton, A.S. (2012), The Sociology of Gender: An Introduction to Theory and Research, 2nd ed., Wiley - Blackwell, New York, NY.

Wilson, J. (2010), Essentials of Business Research: A Guide to Doing Your Research Project. SAGE Publications, New York, NY.

Xia, L., Parkes, D. and Soufiani, H. (2012), "Random utility theory for social choice”, available at: https:// doi.org/10.1117/12.2009724

Yates, J., Veinott, E. and Patalano, A. (2003), "Hard decisions, bad decisions: on decision quality and decision aiding", Emerging Perspectives in Judgment and Decision Research, pp. 13-63, available at: http://works.bepress.com/andrea_patalano/18/

Corresponding author

David Edwards can be contacted at: drdavidedwards@aol.com

For instructions on how to order reprints of this article, please visit our website:

www.emeraldgrouppublishing.com/licensing/reprints.htm

Or contact us for further details: permissions@emeraldinsight.com 